\title{
Why Are We Eating Halal - Using the Theory of Planned Behavior in Predicting Halal Food Consumption among Generation Y in Malaysia
}

\author{
Aiedah Abdul Khalek and Sharifah Hayaati Syed Ismail
}

\begin{abstract}
This study aims to examine the determinants of urban Generation $Y$ intentions in consuming halal food in Malaysia. Ajzen's Theory of Planned Behavior is used as a theoretical framework postulates three components which are attitude, subjective norms and perceived behavioral control. Data were collected from 425 Muslims respondents through self-administered questionnaires. The respondents were between 15 to 30 years old residing in Klang Valley Malaysia. Findings of this study demonstrates that the intentions of urban Generation $Y$ consumers in consuming halal food is predominantly influenced by attitude, subjective norms and perceived behavioral control towards halal food. This study extends the insights of the Muslim consumers' behaviors particularly on urban generation $Y$ Muslims behaviors. The practical implication of this study contributes knowledge to the manufacturers in expanding their market and for governmental organizations to stimulate halal consumption in the country.
\end{abstract}

Index Terms-Consumers' behavior, generation Y, halal food, consumption.

\section{INTRODUCTION}

The halal industry is considered as one of the fastest growing industries and is estimated to accelerate further in the world market. The annual global market value for the entire Halal trade is estimated at USD 2.1 trillion, of which 60 percent of it is generated from halal food [1].

The growth of halal trade has rising in Malaysia and other Muslims majority populated countries, as well as in the countries which populated by Muslim minorities for example in the United States and other European countries [2]. Indeed, the demand of halal food in the world market is escalated due to the growth of Muslim population and the increase of purchasing power among Muslim consumers [3]. In Malaysia, halal market is highly supported under the Halal Master Plan introduced in 2008 to meet halal integrity in process, implementation consumption and services. The support to this Plan can be identified also in the Third Industrial Master Plan (IMP3, 2006-2020) and the Tenth Malaysia Plan (2010-2015) [4].

Previous literatures have been discussed about halal consumption theoretically and empirically in different

Manuscript received February 26, 2014; revised April 18, 2014. Thi work is supported by Malaysia Ministry of Higher Education under PhD MyBrain 15 scholarship. Why Are We Eating Halal? A Study of Determinants Influencing Urban Generation Y in Consuming Halal Food in Malaysia.

The authors are with the Academy of Islamic Studies, University of Malaya, Jln Pantai Baru, Kuala Lumpur, Malaysia (e-mail: dejana2000@yahoo.com.my, shasiaq@um.edu.my). context and society. Halal consumption is deliberated from the religious, societal, cultural and business point of views. From the Islamic perspective, Islam is very specific in delineating the details of halal consumption in the Quran and deliberated by Prophet Muhammad SAW. However, it observed that there is lack of empirical research explaining the halal consumption among Muslims and none of the previous research explore on the halal consumption from generation $\mathrm{Y}$ point of view. Generation $\mathrm{Y}$ in this study refers to a demographic characteristic for young group of people whose born duration of 1983-2005 [5].

It has been shown that generation $\mathrm{Y}$ has a unique and different characteristics compared to previous generations. They are heavily consumption oriented, savvy generation, trendsetters and established brand conscious. Thus, data of halal consumption conducted on different generation might not be generalized to generation $\mathrm{Y}$ due to their unique consumption behavior and preferences. In fact, research on Gen Y Muslim consumers is significant because they are the largest and most lucrative consumers [6] for the current and future of the halal industry.

This study aims to examine the determinants which influence urban Generation Y Muslims' intentions in consuming halal food in Malaysia. Therefore, the primary research questions of this study are: 1) Does the attitude have significant influence on the behavioral intentions of Generation Y Muslims in consuming halal food. 2) Does the subjective norms factor have significant influence on the intentions of Generation Y Muslims in consuming halal food 3) Does the perceived behavioral control factor have significant influence on the intentions of Generation $\mathrm{Y}$ Muslims to consume halal food.

\section{FACTORS INFLUENCING HALAL CONSUMPTION}

In conceptualizing the notion of halal, al-Qardhawi (1994) describes it as lawful and permissible. Technically it refers to means the food that is permitted by Allah SWT and there is no restriction from any reliable sources in Islam [7]. Halal food should be prepared, processed and manufactured hygienically so that it is safe to consume and comply with the sharia. These include the process of slaughtering, storing, displaying and preparing of the food [8].

Previous literatures demonstrated the influence of attitude, subjective norms, perceived behavioral control and religiosity on halal consumption in their research. The attitude of Muslim consumers possibly linked to the Islamic ruling of halal consumption as well as the advantages or 
disadvantages that should be delivered from it. From the attitude perspective, the word halal could also perceive as wholesome. The word halal has been mentioned together with the word "tayyib" several times in the Quran. The word "tayyib" means pure, good, wholesome and good quality [9]. It reflects the characteristic of halal goods as wholesome and possesses good quality and do not harm the consumers [10].

The significant influence of attitude, subjective norms and perceived behavioral control were highlighted as the main predictors of halal consumption. Likewise, Suddin Lada et al (2011) found that subjective norm was significant in predicting halal consumption. In addition, a study of 485 Malaysian respondents, family and friends played a major role in determining behavioral intention of Muslims in halal consumption. The author argued that a possible reason of the subjective norms influence is among the characteristic of Malaysian society itself, where Muslims practice collectivistic culture and peoples' behavior are interdependent with the family and society [11].

Recent study by Mohd Sobhi et al. (2013) conducted on 130 Muslim students at one higher education institution in Malaysia shown that subjective norm is important in predicting participation intention to visit "kopitiam"(Chinese coffee shop) and found to be a significant predictor of Halal food awareness. [12] In addition the influence of social behavior on halal consumption plays a certain role in determining halal consumption. For example, the social behaviors of Muslim consumers in Malaysia tend to look at halal certification as an assurance of halal food and products. Thus, it is important to understand that the social behavior of the people in the country in order to understand their consumption behavior. The social behavior and social influence could be important determinant in predicting halal consumption among Muslim consumers.

Bonne (2007) conducted a study of halal meat consumption among 576 Muslims who were living in France. He concluded that positive attitude, social influences and perceived behavioral control determined the intentions of Muslims in consuming halal food. However, perceived behavioral control which was the availability of halal meat was not significant in predicting halal consumption. Furthermore, the study revealed that even though halal food is not easily accessible, Muslims were willing to put an effort in consuming halal food. He added that social structures such as people's origin and generation differences were contributing factors in predicting dietary preferences of consumers as well [13].

In the context of Malaysia, the halal consumption among Muslim consumers may as well be influenced by the current challenges faced by them in the multicultural society. The availability and accessibility of alcohol and the gambling industry, capitalism and socialism monetary system and globalization were identified as challenges of Muslims in consuming halal food. The availability and accessibility of non-halal food and drinks at some urban areas in Malaysia could be one of the reasons for non-halal consumption among Muslims [14]. This indeed reflected the perceived behavioral control factor, as described earlier in this section.

\section{Methodology}

There were few frameworks used to elucidate consumers' behavior towards food. However, the Theory Planned Behavior was among the prominent frameworks used in explaining halal consumption. The TPB was adopted in this study because it was proven effective in predicting consumers' behavior towards halal food [15]. Ajzen Izek (2006), (the pioneer of TPB) stressed on the importance of behavioral intention in predicting the behavior of individual and society. In addition, this fact was adopted in many researches across the academic fields. Ajzen Izek argued that determinants influencing behavioral intention are belief of human being about the possible consequences of the behavior, beliefs about the normative expectations of others, and beliefs about the presence of factors that may ease or obstruct to perform the behavior [16]. It was found that the stronger intention to perform a behavior, the more likely the behavior will be performed [17].

In conceptualizing the determinants influencing halal food consumption in this research, attitude towards behavior is referred to the respondents' favorable or unfavorable evaluation to consume halal food. Secondly, the subjective norm is a perceived social pressure for young consumers in consuming halal food. The third determinant is perceived behavioral control which defined as a belief about individual control of the opportunities and availability of halal food in Malaysia. Hence, the framework yields the following hypotheses:

H1: There is a positive relationship between attitude of Generation Y Muslims and their intentions in consuming halal food.

$\mathrm{H} 2$ : There is a positive relationship between subjective norms and the intentions of Generation $\mathrm{Y}$ Muslims in consuming halal food.

H3: There is a positive relationship between perceived behavioral control of Generation $\mathrm{Y}$ Muslims and their intentions in consuming halal food.

\section{A. Instrument}

The instrument of this study was developed by the researchers based on the TPB framework, which consists of three constructs namely attitude, subjective norms and perceived behavioral control. The items were developed using the guidelines of constructing questionnaire proposed by its pioneer Ajzen Izek.

The first section of the questionnaire comprised of relevant demographics such as age, gender, races and education background. Attitude was measured by 8 items of the favorable and non-favorable respondents' evaluation on halal food as below:

- Eating halal food is important for me.

- I trust to consume halal food compared to non-halal food.

- Halal food is clean.

- Halal food is cleaner compared to non halal food.

- Halal food is safe to eat.

- Halal food is safer to eat compared to non halal food.

- Halal food is healthy.

- Halal food is healthier compared to than non-halal food. The measurement of subjective norms consisted of 6 items as below: 
- Most people who are important to me choose Halal food.

- People can influence me to eat halal food.

- My family members prefer halal food.

- Eating halal food is being practiced in my family.

- My friend would think that I should choose halal food.

- My family imposes on me the importance of eating halal food.

Perceived behavioral control was tested using 5 items as below:

- It is easy to find halal food in Malaysia.

- It is easy to find halal food in my University.

- I always have chance to eat halal food.

- There are many choices of halal food in my University.

- Price of halal food is reasonable.

The dependent variable (behavioral intention) was measured by 7 items as below:

- I will not eat if the food is non-halal.

- I will not eat if the food is doubted as halal.

- I will eat only in halal food outlets.

- I will eat only halal food.

- I will make sure that the food is halal before I consume it.

- I will make sure the food is halal before I purchase it.

- I will not consume the food if it is prepared using any non-halal ingredients for example alcohol.

A five point Likert scale was used to measure the constructs, ranging from "strongly disagree (1) to "strongly agree (5). The questionnaire was validated by 3 scholars in the field and was pre-tested by 20 respondents, in order to ensure its content validity. Based on the comments from the scholars, few amendments were made to the instrument. Prior to the actual survey, a pilot study was done with 52 respondents. Factor analysis was conducted in order to ensure the validity of measurement items by using principal component analysis. An Eigen value of more than one was used to determine the criteria for each factor in factor analysis The result of factor analysis showed that each instrument exceeded 0.6, which met the essentially significant level of convergent validity.

The reliability of the items in this study was verified by computing the Cronbach's alpha. Nunnally (1978) recommended a minimum alpha 0.7 for basic research reliability [18]. Table I shows the Cronbach's alpha projected scale each variable reaches the minimum alpha of 0.7 . Therefore, the reliability of the constructs was considered high and acceptable for this study.

TABLE I: RELIABILITY COEFFICIENT

\begin{tabular}{||l||c||c|c||}
\hline \multicolumn{1}{|c||}{ Variables } & Number of items & Items dropped & Cronbach $\alpha$ \\
\hline \hline Attitude & 8 & - & 0.883 \\
\hline \hline Subjective Norm & 6 & - & 0.775 \\
\hline \hline $\begin{array}{l}\text { Behavioral } \\
\text { Control }\end{array}$ & 5 & - & 0.781 \\
\hline \hline $\begin{array}{l}\text { Behavioral } \\
\text { Intention }\end{array}$ & 7 & - & 0.955 \\
\hline
\end{tabular}

\section{FINDINGS}

A random sample of Generation Y Muslims was drawn upon from 5 Private Universities in Klang Valley. Age, religion and education level of homogeneous sample were used since the objective of this study is to identify the factors influencing Generation Y Muslims' in consuming halal food. 600 questionnaires were distributed to undergraduate students and a total of 425 questionnaires were completed by the respondents. Descriptive analysis and correlation methods were used to explain the relationship between dependents and independent variables in this study. Normality test using Shapiro Wilk was carried out and the values for all variables are below 0.05 . The findings of this study present the influence of three independent variables; attitude, subjective norms and perceived behavioral control of Generation Y Muslim consumers to the behavioral intentions in consuming halal food.

\section{A. Respondents Profiles}

Descriptive analysis was used to analyze the demographic information of the respondents such as gender, age and education. 245 respondents were female $(57.6 \%)$ and 180 $(42.4 \%)$ were male. 13 respondents $(3.1 \%)$ were between $15-17$ years old, 270 respondents $(63.5 \%)$ were $18-20$ years old, 101 respondents $(23.8 \%)$ were $21-23$ years old, 31 respondents $(7.3 \%)$ were $24-26$ years old and 10 respondents $(2.4 \%)$ were between $27-30$ years old. The respondents gathered for this study were from seven different fields of studies which offered by Private Universities. 24\% respondents from Business Studies, 13.4\% from Bioscience, $19.1 \%$ from Computer/Information Technology Studies, $5.9 \%$ from Social Science/Language, $30.8 \%$ from Technical/Skills Studies and $6.8 \%$ from other fields of study. All respondents were undergraduate Malaysian students in five Private Universities in Klang Valley.

\section{B. Descriptive Statistics}

Table II presents the mean scores and standard deviations of the constructs used in this study according to Theory of Planned Behavior. Mean scores are presented based on five point Likert scale (1 - 5). In general, respondents' attitude was rated at 4.79 , subjective norm at 4.72 and perceived behavioral control at 4.57 and behavioral intention in consuming halal food at 4.70. Attitude was identified with the highest mean for score at 4.79 , showing that majority of respondents' had a positive attitude towards halal food. The mean of behavioral intention to consume halal food is considerably high (4.57) which is between agree and strongly agree.

TABLE II: DESCRIPTIVE FINDINGS OF HALAL OF ALL CONSTRUCTS

\begin{tabular}{||l|l||l|}
\hline Constructs & Mean & Std. Deviation \\
\hline \hline Perceived Behavioral control & 4.5719 & .53827 \\
\hline \hline Attitude & 4.7901 & .42476 \\
\hline \hline Subjective norms & 4.7229 & .50456 \\
\hline \hline Behavioral Intentions & 4.7052 & .63794 \\
\hline
\end{tabular}

*1=strongly disagree; $5=$ strongly agree

\section{Hypotheses Testing}

The three hypotheses were tested using correlation analysis and the result for correlation is presented in the Fig. 2. Table III indicates the correlation coefficient between subjective norms and the intentions to consume halal food is significant, and the strongest at $(0.517 p<0.01)$. This followed by correlation coefficient between attitudes and the 
intentions to consume halal food $(0.535, p<0.01)$. The correlation between perceived behavioral control and intentions to perform the traditions is also significant at $(0.314, p<0.01)$ but lower compared to the other two factors. Therefore, all the three null hypotheses of this study are rejected.

TABLE III: RESULT OF CORRELATION ANALYSIS

\begin{tabular}{|c|c|c|c|c|c|}
\hline & & ATT & SN & PBC & BI \\
\hline \multirow{2}{*}{$\begin{array}{l}\text { Attitude } \\
\text { (ATT) }\end{array}$} & $\begin{array}{l}\text { Pearson } \\
\text { Correlatio } \\
\mathrm{n}\end{array}$ & 1 & $.561^{* *}$ & $.374^{* *}$ & $.517^{* *}$ \\
\hline & $\begin{array}{l}\text { Sig. } \\
\text { (2-tailed) }\end{array}$ & & .000 & .000 & .000 \\
\hline \multirow[b]{2}{*}{$\begin{array}{l}\text { Subjective } \\
\text { norms } \\
(\mathrm{SN})\end{array}$} & \multirow{2}{*}{$\begin{array}{l}\text { Pearson } \\
\text { Correlatio } \\
\mathrm{n} \\
\text { Sig. } \\
(2 \text {-tailed) }\end{array}$} & $.561^{* *}$ & 1 & $.390^{* * *}$ & $.535^{* *}$ \\
\hline & & .000 & & .000 & .000 \\
\hline \multirow{2}{*}{$\begin{array}{l}\text { Perceived } \\
\text { Behavioral } \\
\text { Control } \\
\text { (PBC) }\end{array}$} & \multirow{2}{*}{$\begin{array}{l}\text { Pearson } \\
\text { Correlatio } \\
\mathrm{n}\end{array}$} & $.374^{* *}$ & $.390^{* *}$ & 1 & $.314^{* *}$ \\
\hline & & .000 & .000 & & .000 \\
\hline \multirow{2}{*}{$\begin{array}{l}\text { Behavioral } \\
\text { Intention } \\
\text { (BI) }\end{array}$} & \multirow{2}{*}{$\begin{array}{l}\text { Pearson } \\
\text { Correlatio } \\
\mathrm{n} \\
\text { Sig. } \\
\text { (2-tailed) }\end{array}$} & $.517^{* *}$ & $.535^{* *}$ & $.314^{* *}$ & 1 \\
\hline & & .000 & .000 & .000 & \\
\hline
\end{tabular}

\section{DisCUSSIONS}

This study reveals the factors that influenced Generation $Y$ in choosing halal food are determined by their attitude and subjective norms. The result shows that positive attitude towards halal food is the most important factor influencing the behavioral intention in consuming halal food. Indeed, this finding confirms the study of Syed Shah Alam \& Nazura (2011) which showed that attitude was an important factor in predicting intention to consume halal food [19]. In line with that Aitelmaalem, et al. (2005) did stress on the influence of consumers' attitude in determining the halal food consumption among Muslims [20]. Knowing the fact that positive attitude is the most vital factor in determining halal food consumption, creating positive image and perception of halal food, may possibly augment the demand of halal food. The positive image of halal food could be promoted through the aspects of quality assurance, health and hygiene of the halal food.

Subjective norms are also found significant in choosing halal food among young consumers in this study. The significant influence of subjective norms in this study is contradicts with the finding of Liou and Contento (2001) which showed that the subjective norms did not have positive influence towards food behavioral intention [21]. In contrary, this study in line with the findings of Aiedah (2014), which revealed that subjective norm was significant in determining consumers' attitude on halal food [22]. The significance influence of subjective norms in Malaysia could possibly relate to the characteristics of Muslim society in Malaysia practices collectivistic culture in the society. Therefore, generally social influence for example family, friends and colleagues are strong determinant points on halal consumption in Malaysia.

Third determinant, perceived behavioral control portrays significant role in predicting Generation Y's intention on halal consumption in this study. This finding contradicted with the study conducted by Bonne et al. (2006) which revealed that behavioral control was not an important predictor on intention in choosing halal food. According to Bonne et al. (2006), the availability of the halal food is not the main determinants of halal consumption as Muslims were willing to put their effort in getting the halal food as prescribed by Islam [23]. However, this study supported the finding of Armitage \& Corner (2001) which confirmed that perceived behavioral control was found as a significant determinant of consumer behavior [24]. Hence, as perceived behavioral control factor is concerned, the availability and price of halal food which falls under the perceived behavioral control factor did influence Generation $\mathrm{Y}$ decision in consuming halal food.

\section{CONCLUSION}

The result of this study showed that the TPB is an effective model that can be used to predict intention in consuming halal food. It was demonstrated that the factors influencing Generation Y urban Muslims in halal food consumption mainly because of their positive attitude towards halal food, social influences especially influences from family and friends and perceived behavior control to consume halal food. Therefore, this study suggests that Government and marketers may incorporate the element of attitudes and social pressure in their halal food campaigns and advertisements. The availability, variety and price of halal food also need to be given attention by Malaysian government. In addition, knowledge and awareness on halal food could be incorporated in the existing Islamic Studies subject at the school level for young Muslims to inculcate the right understanding about halal food. Future research may broaden the population and expand the geographical locations to other states in Malaysia. The influence of other potential determinant for example religiosity on halal consumption may as well be looked into in future research.

\section{REFERENCES}

[1] Halal Industry Development Corporatio. [Online]. Available: http://www.hdcglobal.com/publisher/bhi_market_information\#synops is

[2] Z. M. Bistari "Halal certification scheme," Standard and Quality News, vol. 11 , no. 4 , pp. 1,2004

[3] N. M. Aris and A. A. Rahman, "Perlaksanaan dasar sekuriti makanan di Malaysia: kajian daripada perspektif ekonomi," Islam Shariah Journal, vol. 19, no. 1, pp. 39-62, 2011.

[4] A. M. Bohari, W. H. Cheng, and N. W. Fuad, "An analysis on the competitiveness of halal food industry in Malaysia: an approach of SWOT and ICT strategy," Malaysia Journal of Society and Space, vol. 9, no. 1, pp. 1-11, 2013

[5] J. Markert, "Demographics of age: generational and cohort confusion," Journal of Current Issues and Research in Advertising, vol. 26, no. 2 pp 11-25, 2004. 
[6] K. M. R. Johnson, "Generation y consumer choice for organic foods," Journal of Global Business Management, Wales University, vol. 7, no. 1, pp. 2-13. 2011.

[7] Y. al Qardhawi, "Al halal wal al haram fil al-islam," Kaherah: al Maktab al Islami, 15th ed. 1994, pp.17.

[8] S. Shafie and M. N. Othman, "Halal certification: an international marketing issues and challenges: Malaysia standardization for halal food," Standard and Quality News, vol. 11, no. 4, pp. 9, August 2004.

[9] A. bin M. Yunus, W. M. Y. bin W. Chik, and M. B. Mohamad, "The concept of halalan tayyiba and its application in products marketing: a case study at Sabasun Hyperruncit Kuala Terengganu, Malaysia,' International Journal of Business and Social Science, vol. 1 no. 3, pp. 239-248, December 2010.

[10] A. A. Adnan, "Islamic consumer behavior (ICB): its why and what," International Journal of Business and Social Science, vol. 2, no. 21, pp 157, 2001.

[11] S. Lada, H. T. Geoffrey, and H. Amin, "Predicting intention to choose halal products using theory of reasoned action," International Journal of Islamic and Middle Eastern Finance and Management, vol. 2, pp. 66-76, 2009.

[12] M. S. Ishak, M. Ahmad, M. Nizho, and M. K. H. Rofie, "Predicting intentions to visit kopitiams as halal food outlet: an extension of the theory of planned behavior," in Proc. 4th ICBER 2013 Conf., Bandung Indonesia.

[13] K. Bonne, I. Vermeir, B.-B. Florence, and W. Verbeke, "Determinants of halal meat consumption in France," British Food Journal, vol. 109, pp. 367-386, 2007.

[14] S. A. Rahman and J. Abdullah, "Tuntutan Menggunakan Produk Dan Perkhidmatan Halal Menurut Pandangan Syariah," Fahrul Irfan Ishak, Serdang Penerbit Universiti Putra Malaysia, 2011, ch. 7, pp. 135-159.

[15] P. Sparks and R. Sheperd, "Self -identity and The Theory of Planned Behavior: assessing the role of identification with green consumerism," Social Psychology Quarterly, vol. 55, no. 4, pp. 388-399, 1992.

[16] I. Ajzen. Constructing a Theory of Planned Behavior questionnaire. [Online]. pp. 1. Available: http://www.people.umass.edu/aizen

[17] I. Ajzen, "The theory of planned behavior," Organizational Behavior and Human Decision Processes, vol. 50, pp. 179-211, December 1991.

[18] J. C. Nunally and H. B. Ira, Psychometric Theory, 2nd ed. New York: McGraw-Hill, Inc., 1978, pp.245.

[19] S. S. Alam and M. S. Nazura, "Applying the theory of planned behavior (TPB) in halal food purchasing," International Journal of Commerce and Management, vol. 21, no. 1, pp. 8-20, 2011.

[20] H. Aitelmaalem, P. Breland, and L. R. Zayak, "Canadian halal meat market study," Agriculture Food and Rural Development, 2005.

[21] D. Liou and I. R. Contento, "Usefulness of psychosocial theory of variables in explaining fat-related dietary behaviour in Chinese American: association with degree of acculturation," Journal of Nutrition Education, vol. 33, no. 6, pp. 322-331, 2001.
[22] A. K. Aiedah, "Young consumers' attitude towards halal food outlets and JAKIM's halal certification in Malaysia," Procedia-Social and Behavioral Science, vol. 121, pp. 26-34, 2014.

[23] K. Bonne and W. Verbeke, "Muslims consumers attitude towards meat consumption in Belgium: insights from a means-end chain approach," Anthropology of Food, vol. 5, pp. 367-389, 2006.

[24] C. J. Armitage and M. Conner, "Efficacy of the theory of planned behavior: a meta-analytic review," British Journal of Social Psychology, vol. 40, no. 4, pp. 471-499, 2011.

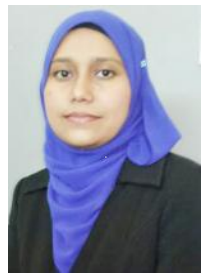

Aiedah Abdul Khalek was born in 1975 and originally from Perak, Malaysia. She received her bachelor of Islamic revealed knowledge and heritage from the International Islamic University, Malaysia in year 2000. She obtained her master in sharia from the University of Malaya in 2003 and currently doing her Ph.D. in Sharia in the same University. She is now a lecturer and a module leader in Taylors University Malaysia since 2007. Her research interests include areas on hala consumption, halal governance, and action research for teaching and learning.

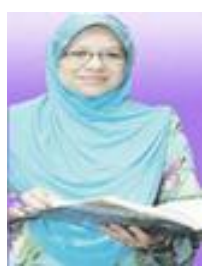

Sharifah Hayaati was born in 1969 and originally from the state of Johore, Malaysia. She received her bachelor degree of sharia from the University of Malaya, Kuala Lumpur, Malaysia in 1992. Master in comparative laws from the International Islamic University of Malaysia in 1994 and $\mathrm{Ph} . \mathrm{D}$. in policy studies and public administration from the University of Bristol, England in 1997. She is now an associate professor in the field of comparative administration since 1997 at the Department of Islamic Political Science, Academy of Islamic Studies, University of Malaya, Kuala Lumpur. She was a receiver of fulbright specialist award in 2007. Besides lecturing she is actively involve with community service in various forms and levels in Malaysia and Singapore. She wrote books titled, "Civil Servant Ethics from an Islamic Perspective" (Kuala Lumpur: Dewan Bahasa \& Pustaka Press, 2010), co-author for "Quality Services From Islamic Perspective" (Kuala Lumpur: University Malaya Press, 2013) and editor to "Effective Governance" (Kuala Lumpur: University Malaya Press, 2004). Her research interests include areas on values and ethics in administration, strategic planning, governance and women leadership. Dr. Sharifah Hayaati is a panel member for muslim Women issues, Department of Islamic Development Malaysia. 